\title{
THE QUR'ĀNIC MODEL ON SOCIAL CHANGE: FAMILY STRUCTURE AS A METHOD OF SOCIAL REFORM
}

\author{
Zainab Alwani*
}

\begin{abstract}
Islam emphasises the belief that the family is the cornerstone of human civilisation. This article explains that Islamic teachings regarding family structure are unique in providing theoretical and practical answers to modern challenges and have the ability to reform any deviation. Furthermore, it constructs, from the study of the Qur'ān and the prophetic applications, a model for gender equality and harmonious family relations. The methodology of this article is based on conducting a textual analysis of relevant qur'ānic concepts and Prophetic applications. It is my hope that having this understanding may show the way towards realising the significance of enforcing gender equity in order to establish healthy and peaceful human relations, especially among family members, which in turn will lead to generating a peaceful human culture and society in our modern time.
\end{abstract}

\section{Core Values}

The essence of the qur'ānic model is rooted in tawhìd - the Oneness and Uniqueness of God. From the doctrinal standpoint, the greatest injustice that one can do to oneself is to deny God, or more pointedly, to associate others with God. The concept of tawhìd secures humanity against its own excesses and deviations which constitutes the essence of zulm injustice and oppression. "The concept of zulm is a rich and flexible one as it includes the idea that injustice is not just a category which applies to inter-human relations, but that it also applies to abuse of oneself, willful and knowing or otherwise. This is the category of zulm al-nafs (self-wronging), a category which pre-eminently invokes a human moral responsibility of the first order."1

The Qur'ān emphasises that God created human beings - men and women - to worship and serve Him as khulafä' (pl. of khalīfah), representatives or trustees of God.

* Zainab Alwani is the Program Director and an Adjunct Professor of Arabic Language Studies at Northern Virginia Community College and an Adjunct Professor of Arabic Studies at the School of Advanced International Studies, Johns Hopkins University, United States. 
Behold! Thy Lord said to the angels: "I will create a vicegerent (trustee) on earth." (2:30)

It is essential to understand the relationship between God and each individual before engaging in a discussion on the relationship between human beings. Each human being, whether female or male, is directly accountable to God for his or her behaviour. In order to fulfil the mission of vicegerency (khiläfah), people must engage in an ongoing process of self-purification (tazkiyah $\left.{ }^{2}\right)$. This process involves sorting through the myriad of emotional impulses that may plague human beings and lead to internal conflict and struggle regarding the actions one should pursue.

O mankind! We created you from a single (pair) of a male and a female, and made you into nations and tribes, that you may know each other (not that you may despise each other). Verily, the most honored of you in the sight of God is the most righteous of you [...]. (Qur'ān 49:13) $)^{3}$

In this case, the only aspect by which one person is deemed better than another in the sight of God is that of piety.

Therefore, taqwā (piety or God consciousness) is an essential concept in understanding the depth and degree to which the religion of Islam impacts the daily life of each Muslim. Maintaining an awareness of God's presence and His will shapes the thought processes and behaviours in the individual, familial, societal and spiritual domains. It serves to determine priorities, direct decision-making, regulate interactions with others, and monitor one's relationship with the Creator. It is often described in the Qur'ān as 'moral perfection' (iḥsān) that protects the person from harming others. As the Qur'ān states:

Those who have taqwā, when a thought of evil from Satan assaults them, bring God to remembrance, whereupon they begin to see clearly. (8:2)

The Qur'ān teaches that God has given people the freedom to choose which path to take in every decision of life. He has also outlined the consequences of these choices. ${ }^{4}$ On the Day of Judgment, every person will be held accountable for choices made during his/her life. This concept of accountability is central to the Islamic paradigm in general, and has particular relevance to the prevention and treatment of injustice in general, and more specifically, within the family.

In order to maintain justice, balance and transparency of the Islamic legal and social framework, Islam presents a comprehensive system of rights where the rights align with responsibilities. It is inspired by its law, the shari $a h .^{5}$ It became part of a social contract or covenant between humans and their Creator and among themselves. It emphasises that every right (haqq) thus has a reciprocal obligation. This framework of the rights-responsibilities system creates just and peaceful human relations instead of conflict and imbalance. Women and men begin asking about 
their roles instead of their rights. It becomes clear that the husband's responsibility is the wife's right in this relationship, and the parents' responsibilities are the children's rights.

Islam emphasises the significance of qiyām (ethics, virtues, and values). Therefore, instead of just relying on technical and material dictations of relationships, Islam promotes a social moral conscience that begins with $m a$ ' $r u ̈ f$ (forgiveness, goodness, and sincerity) and ends with ma 'rüf. Ma'rüf has a broad meaning - kindness and what is known as 'good behaviour', according to social norms and does not go against the shari 'ah. This causes rights and responsibilities in Islam to be a space or arena for competing for the betterment of humanity. This is exemplified in the relationship between husband and wife, that each spouse forgives the other for his/her shortcomings and encourages the other to do better. God has provided a mechanism to regulate and balance human relationships by prescribing behaviours that benefit relationships and prohibiting those that damage relationships. For example, God describes spying, mockery, and back-biting as prohibited behaviours that can destroy relationships, ${ }^{6}$ while being honest, trustworthy, truthful, just, and forgiving maintains and strengthens relationships.

\section{The Qur'ānic Model on Gender Relations}

Since the Qur'ān clearly explains the mission of humankind on Earth as vicegerents of God, gender roles and relations are well defined. To establish an effective vicegerency, the Qur'ān acknowledges taqwā as the only distinction among men and women. Qur'ānic teachings broadly outline gender roles and relations through concepts such as zawjiyyah (pairing), wiläyah (partnership, alliance and guardianship), and qiwammah (male financial, emotional, and physical responsibility toward his family). The first two concepts apply to gender relations in both the private and public sphere, while qiwammah is more related to private family relations. Therefore, this part of the study deals with women's position in the public sphere, while qiwammah will be studied within the family structure.

The qur'annic concept of zawjiyyah is the original and widely used expression to describe female-male relationship. ${ }^{7}$ Amani Salih explains the concept of zawjiyyah in her article "Pairing and Impairing: Re-Conceptualizing Gender through the Qur'an", and suggests that the meaning is a universal concept:

Grounding in a universal cosmogony, zawjiya is poised to compass and encompass a dynamic axiology. It declares the meaning of a deep rooted unity and similarity, human equality, interdependence, functional integrity, a fair and balanced system of reciprocities, a right-duty distribution, and a basic social equity between both sexes where merit and due recompense are required and not accredited [...]. With this in view, the Qur'an 
unequivocally denies the inevitability of a confrontation between the sexes and dislodges traditional male-bounded authoritarian theories on the gender question. ${ }^{8}$

Therefore, zawjiyyah is very important concept in terms of understanding gender relation in Islam.

The second concept, wilāyah, the Qur'ān outlines as the relationship between men and women as partners ( $\left.a w l i y \bar{a}{ }^{\prime}\right)$ of one another in establishing a healthy family and just society. The Qur'ān says:

Believing Men and believing women are protectors of one another: They enjoin what is just, and forbid what is wrong, they observe regular prayers, practise regular charity and obey Allah and his messenger on them will Allah pour his mercy for Allah is exalted in power, wise. (9:71)

The verse outlines the foundation of gender relations as wilayah in both the private and public sphere. This relationship is committed to a lifetime of striving in the way of God to enjoin what is good and forbid what is wrong, altogether, to fulfil the purpose of humankind's creation as khaliffah. It further expands that concept to give each person (female and male) equal responsibility for their actions and fulfilment of religious duties.

\section{The Qur'ānic Position on Women and the Public Sphere}

Since the beginning of the revelation of the Qur'ān, women were involved in the establishment of the first community along with the men. This article provides six points that are derived from the Qur'ān. They indicate God's encouragement for women to contribute publicly to society.

1. The divine reward/punishment system is based on deeds of each individual that reflect righteousness and piety; it is not based on gender, class, colour, ethnicity or wealth: "O mankind! We created you from a single (pair) of a male and a female, and made you into nations and tribes, that you may know each other (not that you may despise each other). Verily, the most honoured of you in the sight of God is the most righteous of you [...]" (49:13).

2. It is not gender, ethnicity, or race that would determine the type of work people choose in the public sphere. Indeed, each individual has special qualities and talent that better enable him/her to perform a certain societal role; when that role is fulfilled, then society functions more effectively. The Qur'ān says, "And do not wish for that by which God has made some of you exceed others. For men is a share for what they have earned, and for women is a share for what have earned. And ask God for His bounty. Indeed God has full knowledge of 
all things" (4:32). ${ }^{9}$ In verse 3:195, the Qur'ān explains clearly that there is no exclusive type of work for each gender. Islamic law has given women the right to own and dispose of their wealth and assets without any guardianship over her, so that she could be a full legal person possessing the full right to manage her wealth. Islam provides her with specific sources to acquire wealth like dowry, inheritance, gifts and all other lawful means for gaining wealth. Furthermore, the Qur'ān presents socio-economic and legal reforms through the ruling of "female testimony" 10 and other laws, especially during the time of the revelation in Arabia, where the norm was women had no access to possess or own anything. According to the holistic reading of the Qur'ān, this verse on female testimony is a permission and preparation for the women to get involved in financial transaction, trade, and business. The Divine ruling allowed women to participate in this field; at the same time it protects her with a backup plan. Today, business backup plans are created to prevent chaos from occurring when business is having a financial, legal, or social crisis. The Qur'ān in this case offers a safety plan to protect the woman from any kind of future legal, social or financial harm that may occur in various situations and under any circumstances.

3. The Qur'ān continues its guidance on setting the highest expectations of people performance. ${ }^{11}$ There are many verses that emphasise this meaning, for example, "And say: work (righteousness) soon will Allah observe your work, and His messenger, and the believers: soon will you be brought back to the Knower of what is hidden and what is open, then He will show you the truth of all that you did" (9:105). The Qur'ān emphasises, "To all are degrees (or ranks) according to their deeds. For thy Lord is not unmindful of anything that they do" (6:132).

4. The concept of wilayah reflects teamwork that is based on universal values and ethics. Wiläyah means when men and women work together toward the ultimate goal of building human civilisation that is based on ethics and higher values. The Qur'ān says, "Believing men and believing women are protectors of one another: They enjoin what is just, and forbid what is wrong, they observe regular prayers, practise regular charity and obey Allah and his messenger on them will Allah pour his mercy for Allah is exalted in power, wise" (9:71).

5. The Qur'ān introduces general guidelines for people to be able to develop accurate systems and mechanisms that enable them to create a safe, healthy and productive work environment. Those guidelines are mentioned throughout the Qur'ān. ${ }^{12}$

6. Shüra (mutual consultation) is an important and practical principle, which is essentially a decision-making process among equals. It infers a level of equality among those consulting and being consulted in order to reach a collective decision. Core values, modesty/the dress code for both men and women, increase the focus on the value of one's work instead of the physical attraction. 
Sürah 24 is the detailed chapter in regard to gender interaction. Women's dress code or hijāb in this case becomes Divine encouragement for women to be involved in the public sphere. The focus of gender interaction should be on the intellectual, spiritual, and social contribution of the individual to the community and humanity at large instead of her physical attraction.

Women were among the earliest converts to the faith, and among the first to sacrifice and be persecuted in the cause (the first martyr was a woman) and significantly, they participated in all the formative community experiences, including specifically the acquisition and transmission of knowledge, which was the source of identity and power in the new community. Women were encouraged to partake in societal duties; even in the war zone. For example, Nusaybah bint Ka 'b was a soldier who was entrusted with the task of protecting the life of the Prophet and his most beloved companions in the Battle of Uhud. She was on the battlefield, sword in hand, battling the Meccan enemy side by side with male companions. Therefore, it is deduced that early Islamic society did not restrict or constrain professions based on gender, but rather, focused on personal qualifications and skills. ${ }^{13}$

Muslim women understood their crucial responsibility to seek education and to empower others through knowledge. They realised that the mosque is a place for spiritual and intellectual growth and development for all Muslims. The presence of women at the Prophet's Mosque was apparent. Women were active and regularly attended the prayers at the mosque at all times, including fajr and ish $\bar{a}$ ' (the dawn and night prayers, respectively) during the time of the Prophet. The mosque was for them a place where their spirits were nurtured, their intellects satisfied, and their skills and contributions appreciated and utilised. ${ }^{14}$ Furthermore, the believing women during the time of the Prophet observed and suffered from many pagan customs and traditions in society. For example, Khawlah bint Tha 'labah, was dignified by God in the Qur'ān (58:1) with the title al-mujādilah, 'the woman who disputes'. She earned this title because she complained to the Prophet regarding the pagan custom of zihār. This was held by pagan custom to imply a divorce and freed the husband from any responsibility for conjugal duties, but did not allow the wife to leave the husband's house or to contract a second marriage. Khawlah understood the Islamic paradigm was based on justice and mercy, therefore, she complained to the Prophet. Soon, the revelation came, and God confirmed Khawlah's conviction that what had been done to her was unjust and was henceforth to be prohibited by law. The Qur'ān confirmed Khawlah's concern and names the sürah as al-Mujādilah (58). Her example can be considered as an indication to encourage people to identify their challenges and construct their questions effectively in order to facilitate change.

Since Islam's earliest days, women had been taking a prominent part in the preservation and cultivation of the main sources of knowledge, Qur'ān and Sunnah, 
and this function continued through the centuries. It is so unfortunate that the hadith literature in particular is used to suppress and deny the role, rights and status of women. Therefore, the distinguished work of the contemporary researcher 'Abd al-Ḥalīm Abū Shaqqah on his six-volume encyclopaedia Tahrīr al-mar'ah fì 'aṣr al-risālah (Liberation of women during the Prophet's era) attempted to illustrate the role of women in the society of Medina during the time of the Prophet. ${ }^{15}$ His methodology was based on a holistic reading of the Prophetic society that was based on authentic data and critical analysis. ${ }^{16} \mathrm{He}$ included only the authentic ahādith that were narrated by al-Bukhārī and Muslim. The conclusion of the book highlights collaboration, mutual respect and successful teamwork among men and women as the perfect component of the model society. As a result, he proved that the fragmental reading of the ahādit th led to committing injustice against women for centuries and that influenced the family as well.

\section{Gender Relations: Between Culture and Religion}

It is important to distinguish between Islamic sources, primarily the Qur'ān and Sunnah, and Muslim cultural norms ('urf), which have developed over centuries of integrating Islamic teachings with cultural and traditional practices in different parts of the world. Culture and religion may interact in many ways, leading to a wide range of responses in Muslim families. ${ }^{17}$

The Qur'ān recognises that historically, in many human societies, men had power over women. In pre-Islamic Arab society, for example, many women had very little or no property, status, and/or rights. Afaf Lutfi al-Sayyid Marsot attempted to present an explanation that is based on a socio-economic analysis:

Anthropologists explain how the economic status impacts the role of men and women. In the societies that sustained themselves through hunting, men were the dominant partners because they do the hunting. When such societies evolved into agricultural societies, those societies where the hoe was used treated men and women equally because either gender could handle a hoe; but in societies where the plough was in use, men became the dominant partner [...]. In nomadic societies, such as those of the Arabian Peninsula where transhumance was a way of life, men were dominant because they had to resort to violence to stave off attacks from rival tribes. Yet, some tribes were matriarchal, where the man joined his wife's tribe; others were patriarchal, where the women joined her spouse's tribe $[\ldots]$.

However, the status of individuals in society depends on the mode of production within the society, an economic determinant. She further continued:

The economic determinant is sustained by a political determinant where in all societies men undertook the function of protecting their society from outside aggression and as 
warriors enjoyed a superior status. Consequently, they also developed control of the political functions of society. The third determinant within society is moral cum legal determinant, for which we can read ethics, religion, et cetera. ${ }^{18}$

Therefore, the Qur'ān as the final, universal divine message, warns men (fathers, brothers, husbands, or guardians) against hurting or taking advantage of women. In times of conflict or discord, the reminder of being God-conscious in making choices and decisions was repeated over and over. ${ }^{19}$ These reminders emphasise the spiritual relationship between God and each individual, which helps guide every other human relationship. ${ }^{20}$ Religion sets out guidelines for society to follow. How society applies and interprets these guidelines is a function not only of religion but of economics, politics, social behaviour and circumstances, demographics, and culture; for these elements determined the interpretations derived from the Qur'ān. Thus, religion is only one determinant among many that guide a society. ${ }^{21}$ Throughout the 15 centuries of Islamic history, diversity and plurality have been the main characteristics of Islamic culture and society. Muslim societies throughout history were not static; they, in fact, were very dynamic as was the status of Muslim women.

After delving into the breadth of historical references, it is obvious that the historical concentration and focus was more geared towards political, diplomatic, and governmental events, rather than social, cultural, and familial constructions. However, with the limited and confined historical reference towards societal composition, some modern historians were still able to extract and extrapolate the contribution and reverence of women. The sources that illustrate women's status in society vary between the $a h \bar{a} d \bar{t} t h$ of the Prophet, his biography (sīrah), the biographies of the 'ulamā' (tabaqāt), ${ }^{22}$ the fiqh legacy including the great collections of fatwa $\overline{\mathrm{s}},{ }^{23}$ the judicial precedents $(q a d \bar{a}),{ }^{24}$ and finally Arabic poetry and literature. ${ }^{25}$ However, there is still a great need to review and analyse effectively the vast historical collections in order to shed light on women's roles and status, the family structure, and the social foundation through different times. ${ }^{26}$

It is difficult to determine the exact reasons for the decline of women's involvement in the public sphere in Muslim societies. However, there are some important indications that may enable us to draw a timetable in some locations. Less than three decades after the Prophet's death, new concepts and ideals were introduced. Islamic values were tested due to the counter-offensive of tribal and authoritarian forces. The tribal and patriarchal system quickly regained strength. This influenced the political process and the social structure as well. ${ }^{27}$ Forefront in the casualties was the then emergent concept of the 'new woman' fully responsible, actively engaged and committed, within the family and the ummah at large. It gave way to an older, deep-rooted counterpart of women as inferior subjects. With this understanding women gradually lost the public roles and strength they had gained 
under the Prophet and his successors, the four Rightly-Guided Caliphs (al-khulafä ' al-rāshidūn). ${ }^{28}$ This latent separation and isolation for women was far removed from the outlook and culture that the Prophet promoted and encouraged.

Furthermore, frequent and continuous wars were another important factor affecting the role of women in Muslim societies..$^{29}$ Men became more protective of women, and keeping them at home was one mechanism used by men to control dangerous situations, until it eventually became a norm and tradition in its own right. ${ }^{30}$

This attitude and practice of secluding, sheltering, and isolating women in order to protect the honour and prestige of society was not present in the early Islamic period of Mecca and Medina. In contrast, women in the early Islamic period were encouraged to partake in social endeavours for the betterment of society. However, the large influx of Christians into Umayyad society and government opened the door for other traditions to bring doubt and suspicion on to the traditionally active Muslim women. In her book Women in the Qur'an: Traditions and Interpretation, Barbara Stowasser, a respected Western researcher, explained the influence of the conquered territories as an important reason for the decline in Muslim women's status:

Even though the Islamic conquests had established Islam's message in the conquered territories outside of the Arabian Peninsula where it largely superseded the older, antecedent religions (mainly Zoroastrianism in Iran and Orthodox Christianity in the Byzantine provinces), indigenous culture, customs, and institutions in these areas, in turn, left their imprint on the emerging medieval Islamic civilisation, including much that had to do with the women's status questions. ${ }^{31}$

Moreover, Karen Armstrong explained the issue of the decline of Muslim women's status in her book The Gospel According to Women: Christianity's Creation of the Sex War in the West. She argues that before the arrival of Islam in the seventh century, upper-class women in Byzantine and Sassanid societies and women of the royal harem wore the veil as a mark of their high status. This custom was adopted by elite women in early Islamic society in the same region. Many nomadic women, however, maintained their traditional freedom of movement and less restrictive dress codes even after conversion to Islam. ${ }^{32}$

Barbara Stowasser elucidated further how the inclusion of isra 'iliyyāt and Bible-related traditions in Islamic exegetic literature truly turned the traditional Islamic societal outlook of women upside down. Bible-related traditions such as, "symbolic images of the female's defective nature" and furthermore, the themes of "woman's weakness" and "woman as threat to the male and society" were all integrated into Islamic theologian commentaries and interpretations. ${ }^{33}$ These biblical traditions transformed Islamic socio-perceptions about women, causing society to look at women as devious, unchaste, and deceitful, which is in total opposition to the early Islamic perception of women. This new-found observation 
of women, according to Stowasser, was the cunning influence of Christians and biblical traditions on the Umayyad society.

For example, the Israelite legacy and paradigm was integrated within the exegete literature. Al-T Tabarī, for example, narrated the story of the creation of Eve according to the Israelite story, ${ }^{34}$ even though he explains clearly his opinion regarding the authenticity of the narration, ${ }^{35}$ but still, the other commentators who came after him continued to narrate the same story according to al-Ṭabarī. To a large part, this must be related to the fact that medieval Islamic society was patriarchal to a far higher degree than had been the early Islamic community in Mecca and Medina, first recipient of the qur'ānic revelations. ${ }^{36}$

To summarise, Muslim countries and cultures are a mixture of many factors. Different circumstances created different social attitudes within the Muslim world and among other societies over centuries. Therefore, the classical Islamic methodology signifies diversity of opinion in classical jurisprudence and accepts the effort of any qualified individual to carry out ijtihäd. ${ }^{37}$ The flexibility of applying the law is considered a positive factor that maintains social stability at any time of drastic change. ${ }^{38}$ While some religious scholars in ninth- and tenth-century Iraq were prescribing more restrictive roles for women, elite women in Muslim Spain were sometimes able to bend these rules and mix quite freely with men. ${ }^{39}$ Moreover, during the Mamluk period in Egypt, working-class women played an active part in economic life; it was proven by their contribution under the endowment system. However, it is true, men who led the army also led the polity and the judicial power; and in modern times, women lead the polity, as in Bangladesh and Pakistan and they have judicial powers, as in Indonesia and Sudan.

Yet, the unique role as a 'mother' is the essence of both nature and nurture, and nature and culture. The etymology of $u-m-m$ points to being a 'source and well-spring', in this case, of life. Therefore, it is not surprising that the term ummah has an affinity with umm (mother), given the realisation that the living world is intrinsically rooted in a community of mothers. Psychologists emphasise that the one who teaches the child from birth, and the few years after, has the greatest influence on that child. It is women who teach children social, religious, and ethical values, thus, it is women who help abolish any discriminatory practices a society might have. Although women in many areas of the Muslim world have plugged into a patriarchal system, they still have the power of teaching their offspring to break away from such a system and create the twin-mate of the qur'ānic model. ${ }^{40}$

\section{Family Structure and Social Development}

The Islamic marriage: A method of social and economic development. Marriage in Islam is noble and universally necessary because it brings tranquillity, progeny, and 
continuation of life with purity and responsibility. Marriage provides a legitimate intimate relationship between a man and a woman, and most importantly, it provides a vehicle for the fulfilment of humankind's divine purpose as God's vicegerents through procreation and human relations. ${ }^{41}$ "Marriage is the root which facilitates human procreation and spreads the notion of kinship (qarābah), including both descendants $(f u r \bar{u})$ and ascendants $(u s \underline{u} \bar{l})$. This also requires the regulation of the in-law relationship (sihr), which manifests its crucial significance for the formation of extended family, clan, tribes, and nations." ${ }^{42}$ In order to protect the human race and society, same-sex relations, fornication, and adultery, in all their forms, are prohibited in Islam. Even celibacy, though honourable in intention, is forbidden due to the biological nature of human beings and their need for human companionship. Therefore, the foundation of the Islamic marriage and its purpose are described in the following verse from the Qur'ān:

And among His signs is this: that He created for you mates from among yourselves, that you may dwell in tranquillity with them, and He has put love and mercy between your (hearts). Verily in that are signs for those who reflect. (30:21)

This verse refers to the main objective of the shari' $a h$ for marriage, which is to establish sakinah (roughly translated as 'tranquillity'). To further enrich this concept of tranquillity, God speaks of another of His favours that He put in the hearts of spouses: compassion and mercy for each other. This verse further specifies the purpose of marriage and characterises the union in which each spouse is responsible for bringing tranquillity into the marriage. It is a reminder that each spouse is inherently equal, and that the union between them is a peaceful and compassionate one. ${ }^{43}$ God further describes the nature of marriage in the following qur'ānic verse:

They are your libās (garments) and you are their garments. (2:187)

As argued by this writer elsewhere,

a garment protects one from the dirt and grime of the outside world. Garments are the closest to our bodies, wrapping us in comfort. Being naturally conscious of appearance, people take time to choose the style, colour, and texture of their clothing, as they take time to clean, iron, and generally maintain it. When the various meanings of libās are translated into the context of a relationship, the parallels are obvious. Men and women are mutual garments for each other. They cover each other's weaknesses, serve as a protection and comfort from the harsh elements of reality, and safeguard the precious intimacy and secrets shared between them. ${ }^{44}$

When two individuals decide to unite in marriage, they are bound by a "solemn covenant". ${ }^{45}$ It is important to understand the significance of the marriage contract and it is an obligation to fulfil all the conditions of the contract from both parties. 
Both man and woman have the right to sign any conditions as long as they do not violate the divine teachings. The objective of the sharī $a h$ is to consider the family as the foundational institute of human society. In order to build stability in the family, the man and woman should enter marriage with the intention of seeking a permanent relationship.

Therefore, choosing the right spouse is crucial. There are many issues on which the Qur'ann provides a comprehensive vision, one of which is for the role of the guardian, wali, as it is explained in 9:71-2. Men and women are guardians of one another, they enjoin what is good and forbid what is evil; this is significant in the early stages of marriage for many reasons. First, the wiläyyah in marriage, according to Islam, is a great responsibility that requires justice, mercy, and wisdom. Second, the role of the wali in a marriage contract is to represent the woman; therefore, he must consult with her throughout the process and ensure all her rights are preserved and protected. Nevertheless, one of the most widespread legal schools, the Hanafi legal school, allows an adult woman to marry without the permission of her wali. Third, the concept of wali declares the approval and full support of the family and the society to the young couple in this crucial stage of their life. ${ }^{46}$ The challenge is what if the wali does not represent the interests of the woman; what recourse does she have? Women have the right to refuse the man for a valid reason. For instance, Islam provides guidelines concerning the social equality of partners with regard to piety, wealth, nasīb (blood ties), profession, education, and even age. It is important for a successful marriage to be established with complete agreement and compatibility between the couple. One can find greater equality among spouses where the spouses have the same or close age, the same degree of wealth, and the same degree of education. ${ }^{47} \mathrm{Next}$, if all the parties agreed with attendance of two witnesses, then the fulfilment of the contract becomes an obligation. ${ }^{48}$ Then, the publicity of the marriage becomes essential. Keeping marriage a secret brings it closer to adultery and preventing people from honouring and protecting this institution. The publicity of marriage aims to achieve the objective of protecting and honouring the rights of all the members of the new family. ${ }^{49}$ Therefore, when we understand the wiläyyah in light of the Qur'ān, it changes from being a dry legal issue to being a qur'ānic moral component.

Islam ensures women's financial rights by instituting a number of laws, including the obligatory mahr (marital gift). The Qur'ān explains it clearly: “And give unto women their marriage portions in the spirit of a gift, but if they, of their own accord, give up unto you aught thereof, then enjoy it with pleasure and good cheer." ${ }^{\prime 50}$

The qur'ānic term nihla $h^{51}$ signifies the 'giving of something willingly', of one's own accord, without expecting a return for it. ${ }^{52}$ It is a gift from the groom to the bride and it reflects his serious commitment to his wife. Mahr can vary greatly in terms of value and type, but should conform to what is customary in the couple's 
cultural and socio-economic context. ${ }^{53}$ The father or any other male figure in her family has no right to take it. It is her financial right, as the Qur'ān and the Sunnah of the Prophet explained. Moreover, the inheritance system in Islam is another avenue for empowering women financially. The Qur'ān encourages women to get involved in the economic growth of the family and the society through the system of zakāt, charity, and endowments (awāqf).

\section{Qiwāmah as Responsibility Allocation}

Men are $q a w w \bar{a} m \bar{u} n^{54}$ over women, because God has given the one more (strength) than the other, and because of the sustenance they provide from their own means. Therefore, the righteous women (al-șālih $\bar{a} t)$ are devoutly obedient to God (qānitūt), and guard what God would have them guard (hâfizā $t^{\text {thn }} l i$ 'l-ghayb) [...] (Qur'ān 4:34-5).

The word qawwämūn was mentioned in only three verses in the entire Qur'ān; two of them call upon believing men and women to establish justice as an ultimate goal in any situation..$^{55}$

O you who believe stand out firmly for Justice as witnesses to God even as against your parents, or your kin, or whether it be against rich or poor. Follow not the lusts (of your heart) [...]. (4:135)

The second verse states,

O you who believe! Stand out firmly for God as witnesses to fair dealing, and let not the hatred of others to you make you swerve to wrong and depart you from justice. Be just: that is next to piety. And fear God. For God is well-acquainted with all that you do. $(5: 8)$

Therefore, qawwämūn in verse 4:34 refers to men's responsibility toward women to be fair and compassionate, as Prophet Muhammad exemplified through his sayings and actions.

Men are responsible for providing a broad range of needs, including financial, spiritual, emotional, and educational needs. Without this divine law, some men may not fulfil their financial responsibility towards their family. Unfortunately, nowadays criticism has been made on the issue of nafaqah (the man's financial responsibility toward his family) to either deprive women of their rights or to make them feel bad about it. Having the man responsible for the financial expenses of his family does not mean women cannot work outside and contribute to their family. Since the time of the Prophet, women were encouraged to be greatly engaged and effectively contribute to their families and society in connection with their qualifications, talents, and circumstances. During the time of the Prophet, some of the women chose to work outside along with their husbands; others decided otherwise ${ }^{56}$ The Islamic 
definition of work goes beyond the modern literal meaning in which it focuses on the value of the contribution, rather than the location of the work. In many cases, men are the breadwinners in their family either temporarily or permanently. In case of death, illness, studying, divorce, or similar circumstances, women take over the burden of financial responsibility in addition to their other responsibilities. Islam encourages women always to be educated and trained so they will be able to support themselves and others in case of an emergency. Therefore, Islam highly respects and trusts women and their abilities to handle multiple tasks, by giving them freedom to choose when it comes to financial support of their families.

Men and women are partners in the endeavour of maintaining a healthy family unit in which children are raised to be God-conscious members of society. The comprehensive system of nafaqah (financial assistance), inheritance, and 'taboos' (mah̄ārim $)^{57}$ in Islam reflect the miraculous design of internal and unspoken contract among the family's members. ${ }^{58}$ The clear crafting of the policy of the rights and obligations in the family reveals the magnitude of this contract in every family relation. It leaves no person without a network that he/she relies on in the time of prosperity or depression. The philosophy of the extended family system in Islam plays the role of preserving and maintaining the welfare of every individual as a member of that family. Amazingly, for instance, in the case of a child who was born as a result of wrongdoing (adultery) and no one claims to be his father, the mother's family immediately becomes the official guardian and responsible for his/her well-being. That is why the family's name is significant in Islam because it exemplifies the commitment of the unspoken contract. For example, in the case of adoption or marriage, the child and the woman should keep their family's name due to that contract. ${ }^{59}$

The fact that a husband and wife have different roles to play in the family does not in any way suggest that men are better than women, or that they have God-given power over them. God clearly highlights that the most honoured among humankind are those who are righteous. ${ }^{60}$ Furthermore, the roles of men and women are not mutually exclusive. Both parents must be involved in raising the children. Although each may participate in different aspects of the child's upbringing, both are equally responsible for the overall welfare of the child. The concept of shürä, as essentially a decision-making process among equals, infers a level of equality among those consulting and being consulted, in order to reach a collective decision. ${ }^{61}$ The success of the family is dependent on the joint participation and consultation of both parents. Children can be included in the process of shüra regarding any matter that is ageappropriate. In this way, children learn the inclusive decision-making process of Islam, which they can carry with them when they are with their peers and when they become active members of the society. Through this process, they also learn 
skills such as cooperation, communication skills (including listening), and tolerance, all of which are necessary tools for living within a dynamic and diverse society.

\section{Islamic Divorce: A Peaceful Solution ${ }^{62}$}

Islam constructed a detailed legal system regarding divorce. This article will not discuss the legal arguments and laws of divorce; rather, it will illustrate the general Islamic values and principles that are related to divorce. ${ }^{63}$ The qur'annic and the Prophetic teachings outline the meaning of marriage as an agreement between two parties that have decided to establish a successful institution in which both parties adhere to God's teachings and abide by His boundaries ( $h u d \bar{u} d$ Allāh). Yet if the parties fail to fulfil the conditions of the agreement, then divorce will be the final solution. However, the divorce prescribed by Islam is to preserve the harmony of the family relations and dissolve marriage peacefully with lesser harm; unlike the cruel, ruthless, and humiliating divorce that we see today in some cases. Nowadays, we see spouses dragging each other through the court system in order to drain and degrade the other. Islamic teachings illustrate that when you seek marriage you get married bi 'l-ma 'rūf and you divorce bi-ihsān by remembering the good times ${ }^{64}$ that you had together. ${ }^{65}$ Therefore, the objective of the shari 'ah regarding divorce is to end the marriage peacefully, in order to preserve the human relationship of sihr. All the qur'ānic verses related to this issue emphasise the fulfilment of this objective.

Divorce is allowed in Islam as a last resort when all other efforts at resolving conflict have been used. It is permitted under a wide variety of circumstances, but is especially acceptable when there is any cruelty involved. ${ }^{66}$ It can be initiated by either party, individually or by mutual agreement, but the procedure and process varies depending on who initiates the divorce, and the circumstances around the divorce. It should be noted that there are different schools of thought in Islam; therefore, some leaders may be more conservative than others in the matter of divorce. Many Muslims may not be knowledgeable about the Islamic legal process related to divorce, and they may have some misconceptions about procedural details, as well as the rights of each party in the event of a divorce. ${ }^{67}$

The Qur'ān devotes an entire chapter to the details of divorce. ${ }^{68}$ Emphasis is placed on ensuring spousal and children's rights, acknowledging that these rights are often abused. The Qur'ān holds not only each spouse accountable for making sure these rights are not violated, but also warns the entire community of being punished if these rights are not upheld. ${ }^{69}$ Although there may be hurt feelings on both sides, the Qur'ān advises decision-making from a compassionate stance, encouraging the couple to remember anything good that they shared.

The psychological state of those impacted by divorce is also addressed in the Qur'an. The theme of forgiveness is tied to being conscious of $\mathrm{God}$ and is linked to the healing process. 
Strategies leading to forgiveness include: focusing on the positive aspects that existed in the relationship in order to prevent hatred and anger from taking over, controlling one's anger to avoid acting unjustly, and increasing one's prayers. Furthermore, the awareness that God is aware of everything that happens, and that He will ultimately ensure justice, facilitates the process of forgiveness and may reduce any impulses to seek revenge. ${ }^{70}$

Despite the permissibility of divorce, today in some cultures that are predominantly Muslim, divorced women may be stigmatised even if they have been mistreated by their husbands. These women may also experience difficulty obtaining a divorce from the court. The laws of some countries deny women their God-given right to divorce. These countries are often contradicting qur'ānic teachings and the Sunnah of the Prophet by doing so. Therefore, they are not applying Islamic law even when they claim to be doing so. ${ }^{71}$ The historian Amira El Azhary Sonbol presented this issue clearly in her article "Law and Gender Violence in Ottoman and Modern Egypt" by comparing the modern state legal system to the Ottoman court system in Egypt. ${ }^{72}$ She intended to prove that whenever the Islamic principles and teachings are considered in a system, it will effectively lead to implement justice for all. ${ }^{73}$ Necva B. Kazimov argued almost on the same line as Sonbol in her article "Egypt's Reservations to the United Nations Convention on the Elimination of Discrimination against Women and Women's Rights in Egypt":

Thus after decades of struggle and resistance, it is a sad irony that Egypt's present divorce law fails to guarantee as many rights as some schools of classical Islamic law did, such as khul ' (divorce by mutual agreement or settlement), the most liberal form of divorce accepted by all classical jurists. Indeed, under some schools of classical Islamic law, a woman would not have to forfeit any of her financial rights to maintenance. ${ }^{74}$

It is important to distinguish between the divine law and the human understanding and implications of the law.

The challenge for modern reform movements is to retrieve the prophetic legacy in the context of changed conditions in modern times. Striving for methodological transparency becomes a necessity. It should be based on drawing clear distinctions between the main sources of Islam; the Qur'ān and the authentic Sunnah of the Prophet. This methodology requires true and authentic engagement with the Qur'ān; beginning with the Qur'ān will bring advancement to Islamic studies, social sciences, and socio-cultural reform.

\section{Conclusion and Recommendations}

The family has been used in this study as a model for the implementation of various Islamic values and principles as the means for achieving tranquillity and peace, 
in seeding conciliation and minimising violence. The union between spouses must be based on the qur'ānic concepts of tawhìd (oneness of God) and istikhläf (vicegerency). The family, as the basic constructive unit on which the rest of society is built, must be the environment in which the values of the larger society are developed and strengthened.

The Qur'ān, in its comprehensive teachings, provides the most detail for issues concerning the family, and the Sunnah has provided explanations and examples for implementation. By examining these teachings, it is obvious that the goal is to build and preserve this crucial family unit. The reading of these teachings must be done in a holistic manner, not by partitioning them into individual components, because reading any verse out of context can lead to confusion and misunderstanding.

That is because the shari 'ah's general role is based on ease and mercy; it is meant to be easily adaptable to any society, so that when circumstances change, attitudes can be modified to fit existing situations. Various cultural patterns actively influence the interpretation of the text. The Qur'ān will continue to be open to individual interpretations and readings, as long as its value system and its general rules are preserved and followed.

We may propose the following by way of policy-relevant recommendations:

- The Qur'ān provides comprehensive guidelines for family law reform but the Qur'ān should be read in context and in conformity with its broader objectives and outlook of mercy to all human beings. There is a need to negotiate some aspects of the scholastic figh rules in light of the broader Qur'ān guidelines.

- History and culture of Muslim societies have influenced the development of fiqh as well as the Qur'ān commentaries. Our efforts to improve the conditions of women should be informed by the need to recapture the original impulses of Islam and the exemplary proxies and teachings of the Prophet's lifetime when women were a part of public life and played important societal roles.

- The existing laws of some Muslim countries such as those of Egypt which stop short of reforming its divorce laws on $k h u l$ ' should be revised. "Release them in equity and kindness" is the qur'ānic guideline on divorce which should inform court practice and legislation on divorce.

\section{Notes}

1. Mona Abu Fadl, "Muslim Women Scholars on Women in Islam" (Chicago, Chicago Theological Seminary), 7 November 1990, available online at http://www.muslimwomenstudies.com/English. htm (accessed on 16 April 2011).

2. See Qur'ān 91:7-10: "And by the soul and proportioned it, and inspired it (with discernment of) its wickedness and its righteousness, He has succeeded who purifies it, and he has failed who instils it (with corruption)." 
3. The Qur'ān was revealed in Arabic, and the Arabic text is believed by Muslims to have been preserved in its original form. The Qur'ān has been translated into most of the world's languages, yet only the original text is accepted by Muslims as of divine origin. The present study relies on Abdullah Yusuf Ali's translation unless otherwise noted; see Abdullah Yusuf Ali (tr.), The Holy Quran (Brentwood MD: Amana Corporation, 1993).

4. See Qur'ān 18:29-31: "Say, the truth is from your Lord. Let him who will, believe, and let him who will, reject (it): For the wrongdoers We have prepared a fire whose smoke and flames, like the walls and roof of a tent, will hem them in [...]. As to those who believe and work righteousness $[\ldots]$ for them will be gardens of Eternity, beneath them rivers will flow [...]."

5. See the chapter "The Concept of Reality and Freedom in Islam and Islamic Civilisation", in: Seyyed Hossein Nasr, Islamic Life and Thought (Albany NY: SUNY Press, 1981).

6. See Qur'ān 49:11: "O ye who believe! Let not some men among you laugh at others. It may be that the (latter) are better than the (former): nor let some women laugh at others: it may be that the (latter) are better than the (former): nor defame nor be sarcastic to each other, nor call each other by (offensive) nicknames: ill-seeming is a name connoting wickedness, (to be used by one) after he has believed: and those who do not desist are (indeed) committing injustice."

7. Zainab Alwani, "The Quranic Model to Harmony in Family Relations", in: Maha B. Alkhateeb and Salma Elkadi Abugideiri (eds), Change from Within: Diverse Perspectives on Domestic Violence in Muslim Communities (Great Falls VA: Peaceful Families Project, 2007), 40-1.

8. Amani Salih, "Pairing and Impairing: Re-Conceptualizing Gender through the Qur'an", Women and Civilisation 3 (2002), 17-53.

9. M.A.S. Abdel Haleem, The Qur'an: A New Translation (New York: Oxford World Classics, 2008).

10. It is one of the controversial issues on women's rights in Islam; see Qur'ān 2:282-3.

11. See Qur'ān 4:135: "O you who believe! Stand out firmly for justice, as witnesses to God, even as against yourselves, or your parents, or your kin, and whether it be (against) rich or poor: for God can protect you both. Follow not the lusts (of your hearts); lest you swerve and if you distort (justice) or decline to do justice, verily God is well-acquainted with all that you do."

12. See Qur'ān, sūrahs 2, 3, 16, 24, 27, 28, and passim.

13. See 'Abd al-Ḥalīm Abū Shaqqah, Tahrī̄r al-mar'ah fì 'așr al-risālah: Dirāsāt jāmi 'ah li-nușūss al-Qur'ān al-Karīm wa Sahịhayay al-Bukhārī wa Muslim (Kuwait, 1410AH/1990), 2: 53; Ibn Sa d, Kitāb al-Tabaqāt al-kabīr, ed. Carl Brockelmann (Leiden: Brill, 1904), 8:415; al-Imām Muslim, al-Jāmī' al-ṣaḥ̄ḥ, "Kitāb al-jihād", 5:179-96.

14. 'Ā'ishah 'Abd al-Raḥmān Bint al-Shāṭ̂', Tarājim sayyidāt bayt al-nubuwwah (Beirut: Dār al-Kitāb al-'Arabī, 1984).

15. Abū Shaqqah, Taḥrīir.

16. Some works have referred to the contribution of Muslim women throughout history, but most of them have focused on the mere gathering of data. Perhaps the best example of a traditional work is Ibn Sa 'd's Kitāb al-Ṭabaqāt (vol. 8); a contemporary example is 'Umar Riḍā Kaḥālah, A 'ām al-nisā' (Beirut: Mu'assasat al-Risālah, 1984). These books are beneficial for the researcher at the stage of collecting data. However, Abū Shaqqah's Tahrīr on tracing the gender-relations and its impact on the society in different times and locations through the history of Muslim ummah is vital.

17. See Anne Sofie Roald's Women in Islam: The Western Experience (New York and London: Routledge, 2001) for a more detailed discussion of the integration between religion and culture.

18. Afaf Lutfi al-Sayyid Marsot, "Women and Modernisation: A Re-Evaluation", in: Amira El Azhary Sonbol (ed.), Women, the Family, and Divorce Laws in Islamic History (Syracuse NY: Syracuse University Press, 1996), 39-51.

19. See Qur'ān 65:1-12 for details concerning separation, divorce, reconciliation, punishment for transgressors and reward for those who obey God's laws.

20. Salma Abugideiri, and Z. Alwani, What Islam Says About Domestic Violence (Herndon VA: Faith, 2003).

21. Al-Sayyid Marsot, "Women", 39-44. 
22. Among the works of Muslim historiography which have documented and gathered vast amounts of data regarding events, stories of different people, battles, wars, cities are Muhammad b. Jarīr al-Ṭabarī, Ibn al-Athīr, al-Khațīb al-Baghdādī, Ibn al-Jawzī, al-Mas 'ūdī, al-Dhahhabī, Ibn Kathīr, Ibn Sa'd, and Ibn Khaldūn, to name only some of the most prominent ones. Muslim historians recorded the biographies of the jurists and scholars since the second century AH/eighth century CE. Some of them were restricted to a specific school of thought such as Tabaqāt al-shäf 'iyyah $a l-k u b r \bar{a}$ and its author al-Subki and many other books written in this area. It was noted that female jurists throughout the centuries featured rarely in these books. Therefore, it is important to use a variety of sources in order to illustrate the role and status of women throughout Islamic history.

23. Such as Ahmad Ibn Taymiyyah's Majmū' al-fatāwā al-kubrā and others.

24. There are many works on this issue published by Western universities such as Georgetown, Harvard, Princeton and several others. Certainly, the methodology, the objectives, and the outcome of each study vary. See for example the important debate regarding the issue of the qualified woman being a judge or any political position in Abū Shaqqah, Tahrīr, 2:367-73.

25. Arabic literature, poetry, and storytelling - whether based on false or true stories - played a good role in reflecting and illustrating the role of women in society. See, for instance, Ahhmad Ibn Abī Ṭāhir Ṭayfūr, Balāghāt al-nisā' (Cairo: 1326AH/1908); Shawqī 'Abd al-Ḥakīm, Mawsu 'āt al-fulkūr wa 'l-'asāțīr al- 'arabiyyah (Beirut: Dār al-'Awdah, 1982), and the famous Arabian Nights. See also Fedwa Malti Douglas, Woman's Body, Woman's Word: Gender and Discourse in Arabo-Islamic Writing (Cairo: The American University in Cairo Pres, 1991); Muhammad 'Anānī, al-Mukhtār min ash 'ā'r al-mar'ah al- 'arabiyyah (Cairo: Al-Hay'ah al-Mișriyyah al- 'Āmmah li 'l-Kitāb, 1997); Muḥammad Ḥasan 'Abd-Allāh, Șūrat al-mar'ah al- 'arabiyyah fì 'l shi 'r al-umawī (Kuwait: Manshūrāt Dhāt al-Salāsil, 1987).

26. Many of the contemporary thinkers and historians were able to realise the need of developing a new methodology on reviewing, studying and analysing the Islamic history. The works of history, which were written in different times and for different purposes and objectives, are in need of new reading and analysis. The call for a new methodology on studying this rich legacy is thus valid. Among those who pioneered in this field is Imād al-Dīn Khalīl. See also the monumental twelve volumes project on "International Relations through Islamic History" under the leadership of Nadiah Mahmoud Mustafa (Cairo: The International Institute of Islamic Thought, 1996). See furthermore 'Abd al-'Azīz al-Dūrī, Dirāsāt fì 'l- 'ușūr al- 'abbāsiyyah al-muta'akhkhirah (Beirut: Markaz Dirāsāt al-Waḥdah al-'Arabiyyah, 2007); 'Abd al-'Alīm 'Abd al-Raḥmān Khị̣r, al-Muslimūn wa-kitabāt al-ta' 'rikh (Herndon VA: the International Institute of Islamic Thought, 1993).

27. This was reflected in the works of literature, poetry, and history. See 'Abd al-Raḥmān Ibnn Khaldūn, The Muqaddimah: Introduction to History, tr. F. Rosenthal, ed. N.J. Dawood (Princeton NJ: Princeton University Press, 1967).

28. See Mona M. Abul-Fadl's editorial column to the journal Women and Civilisation 2, (2001). Available online at www.muslimwomenstudies.com (accessed on 14 April 2011).

29. The Qur'ān describes the negative consequences of war in verse 27:34. Muslim societies continue to face ongoing wars and destruction to this day and more research is needed to analyse the impact of wars on women and children.

30. Mazen Hashem, “A Perspective of Islamic Reforming Regarding Women's Issues”, paper presented at the American Center for Civilization and Intercultural Studies, 1993. See also Roald, Women, 160 .

31. Barbara Freyer Stowasser, Women in the Qur'an: Traditions, and Interpretation (Oxford and New York: Oxford University Press, 1994), 23.

32. Karen Armstrong, The Gospel According to Women: Christianity's Creation of the Sex War in the West (London: Tree Books, 1986); Amr Abdalla, "Principles of Islamic Interpersonal Conflict Intervention: A Search Within Islam and Western Literature", Journal of Law and Religion, 15, no. 1-2 (2000), 151-84; Bernard Lewis, Islam from the Prophet Muhammad to the Capture of Constantinople (London: Macmillan, 1976).

33. See Stowasser's analysis on the issue of isrā 'illiyyāt, Women, 23-5. 
34. al-Ṭabarī, Ta'rīkh al-rusul wa 'l-mulūk, ed., Muhammad Abū 'al-Faḍl Ibrāhīm (Cairo: Dār al-Ma ārif, 1960-69), 8:144; al-Mas' ūdī, Akhbār al-zamān (Beirut: Dār al-Andalus, 1980).

35. 'Imād al-Dīn Khalīl in his analysis of al-Ṭabarî's methodology explained that the major goal for him and the other historians is to make sure that all the information he had acquired is written and documented especially in his book of history (Ta'rīkh al-rusul wa 'l-mulük) regardless of the authenticity of the source. This methodology of collecting and preserving the information was also well-known among other Muslim historians, such as al-Mas 'ūdī. See 'Imād al-Dīn Khalīl, Hawla i ādat kitābat al-ta'rīkh al-islāmī (Qatar: Dār al-Thaqāfah, 1986) and idem, al-Tafsīr al-islāmē li 'l-ta'rīkh (Beirut: Dār al- 'Ilm li 'l-Malāyīn).

36. Khalīl, Hawl, 23.

37. John L. Esposito, Women in Muslim Family Law (New York: Syracuse University Press, 2001), 51; Norman Daniel, Islam and the West: The Making of an Image (Edinburgh: Oneworld, 1960).

38. Necva B. Kazimov, "Egypt's Reservations to the United Nations Convention on the Elimination of Discrimination Against Women and Women's Rights in Egypt", American Journal of Islamic Social Sciences 20 (2003), 36-7.

39. See, for instance, Ibn Khaldūn, The Muqaddimah, tr. F. Rosenthal, ed. N.J. Dawood, passim.

40. Abu Fadl, "Muslim Women"; L. Al-Faruqi, Women, Muslim Society, and Islam (Plainfield IL: American Trust Publications, 1988); Al-Sayyid Marsot, "Women", 39-44.

41. Ismail Al-Faruqi, Al-Tawhid: Its Implications for Thought and Life (Herndon VA: International Institute of Islamic Thought, 1991), 130-3.

42. Muhammad Țāhir Ibn 'Āshūr, Maqāsid al-sharī'ah (Tunis: Tunisian Library for Publication, 1970), English tr. Treatise on Maqasid al-Shariah, tr. Mohamed El-Tahir El-Mesawi (London, Washington: The International Institute of Islamic Thought, 2006), 247. See also Ibn 'Āshūr's al-Tahrìr wa 'l-tanwīr (Tunis: House of Tunisian Publications, 1984); Ibn Taymiyyah, Majmū fatāwī al-nikāh wa-ahkāmihi (Cairo: Dār al-Lubnāniyyah al-Miṣriyyah, 1992).

43. Alwani, "The Quranic Model", 51.

44. Ibid.

45. Qur'ān 4:21.

46. 'Abd al-Ghānī al-Maydānī, al-Lubāb fì sharh al-kitāb (Beirut: Dār al-Kutub al-'Ilmiyyah, 1400AH/1980), 3:8.

47. Al-Sayyid Marsot, "Women", 40.

48. See Qur'ān 5:1. There are different opinions among the schools of thought on the issue of al-wali. However, this study attempts to broaden the meaning of wali in its qur'ānic concept that was mentioned in Qur'ān 9:71-2. At the same time this writer understands this concept in the light of the objectives of the shari ${ }^{-} a h$ for the family.

49. This issue was discussed among the jurists throughout the history of this ummah. Some of them allowed the marriage with the minimum conditions without publicity. This refers to the agreement between the husband and the wife, the mahr and the two witnesses. However, the objective of publicity is to protect the welfare of the family. This issue was discussed among all Muslim schools of thought; see 'Abd al-Karīm Zaydān, Al-Mufșal fì ahkā̄m al mar' (Beirut: Al-Risālah, 1993).

50. Qur'ān, 4:4 Muhammad Asad, The Message of the Qur'an (Gibraltar: Dar Al-Andulus, 1984), 102; Jār-Allāh Maḥmūd b. 'Umar al-Zamakhsharī, al-Kashshāf 'an haqā'iq al-tanzīl wa- 'uyūn al-aqāwīl fì wujūh al-ta'wīl (Cairo: Mustafa al-Bāb al-Ḥalabī, 1385AH/1966); Abū 'Abd-Allāh Muḥammad b. Aḥmad al-Ansari al-Qurtubi, al-Jāmi ' li-aḥkām al-Qur'ān (Cairo: Dār al-Kitāb al-'Arabī, 1387AH/1967); Ibn Kathīr, Tafsīr (Beirut: Dar al-Fikr, 1389AH/1970).

51. The term nihlah is translated as 'free gift', based on Yusuf Ali's translation: "And give the women in marriage their dowry as free gift; but if they, of their own good pleasure, remit any part of it to you, take it and enjoy it with right good cheer." The qur'ānic expression for 'dower' is nihlah. It signifies the 'giving of something willingly', of one's own accord, without expecting a return for it. The exact amount of the marriage-gift, mahr, which the groom has to give to the bride has not been specified by the law. It depends entirely on the agreement of the two parties and may consist with anything, even a mere token (see Asad, The Message, 102). Many cultures and legal systems 
apply the dowry system such as Hindu law. One must distinguish decisively between the meaning, the objectives, and the structure of the dowry system. For a detailed sociological discussion of the issue of dower and its meaning in Islam see Hammudah Abd al-Ati, The Family Structure in Islam (Indianapolis IN: American Trust Publication, 1977), 62-70. See also Al-Sayyid Marsot, "Women", 43.

52. Asad, The Message, 102.

53. Abd al-Ati, The Family Structure, 62-70; al-Zamakhsharī, al-Kashshāf.

54. Asad (The Message, 109) explains the word qawwām as following: "The expression qawwām is an intensive form of $q \bar{a}^{\prime}$ ' $i m$ (one who is responsible for or - takes care of - a thing or a person. Thus qāma 'alā 'l-mar'ah signifies 'he undertook the maintenance of the woman' or 'he maintained her'. The grammatical form qawwām is more comprehensive than $q \bar{a}$ ' $i m$, and combines the concepts of physical maintenance and protection as well as of moral responsibility."

55. See the commentaries by Muhammad b. Jarīr al-Ṭabarī, Jāmi 'al-bayān 'an ta' wìl ay al-Qur' ān, ed. Muḥammad Muḥammad Shākir and Aḥmad Muḥammad Shākir (Cairo: Dār al-Ma ārif, 1950-69); Muḥammad 'Abduh and Muhammad Rashīd Riḍā', Tafsīr al-Qur'ān al-hakīm (Tafsīr al-Manār) (Beirut: Dār al-Ma rifah, second printing, n.d.); Sayyid Quțub, F̄̄ Zilāl al-Qur'ān (Beirut: Dār Ihyāa' al-Turāth al- 'Arabī, 1391AH/1971); Sayyid Abul Ala Mawdudi, Towards Understanding the Qur'an, tr. Zafar Ishaq Ansari (London: Islamic Foundation, 1988); idem, "Introduction", in: idem (ed.), Qur'ānic Concepts of the Human Psyche (Lahore, Pakistan: International Institute of Islamic Thought, 1992), 1-14.

56. Abū Shaqqah, Tahrìr, vol. 2.

57. See Qur'ān 4:23 and 24:31.

58. Yūsuf Ibrāhīm Yūsuf, Istrātījiyyāt wa taktīk al-tanmiyyah al-iqtiṣādiyyah fì 'l-islām (Cairo: Al-Ittiḥād al-Dawlī li 'l-Bunūk al-Islāmiyyah, 1981); idem, Al-nafaqāt al- 'āmmah fí 'l-islām: Dirāsah muqāranah (Doha: Dār al-Thaqāaah, 1988, 2nd ed.).

59. See Qur'ān 4:21.

60. Ibid. 49:13 "O humankind! We created you from a single (pair) of male and female, and made you into nations and tribes that you may know each other (not that you may despise each other). Verily the most honored of you in the sight of Allah is the most righteous of you. And Allah has full knowledge and is well-acquainted (with all things)."

61. See Qur'ān 2:233 and 42:38.

62. Asad, The Message; al-Zamakhsharī, al-Kashshāf; al-Qurțubī. al-Jāmi ; Ibn Kathīir, Tafsìr.

63. Many of the contemporary interpreters have discussed the issue of divorce in the light of the modern societal changes. Ibn 'Āshūr was among the reformers who analysed Islamic family law according to the main objectives of the shari 'ah and he considered divorce as a peaceful solution for a failed marriage; see Ibn 'Āshūr, Tafsīr and idem, Maqāșid. Furthermore see Sayyid Quțub, F̄̄ Zilāl. The issue of divorce was extensively discussed in all the Muslim schools of thought from the legal perspective. Ibn Taymiyah too thoroughly discussed this issue in his Fatāwa from the legal and social perspectives; see 'Abd al-Raḥmān b. al-Qāsim (ed.), Ibn Taymiyyah: A Great Compilation of Fatwa (Saudi Arabia: 1966-69).

64. Qur'ān 2:237.

65. Ibid. 2:227-42 and 65:1-12.

66. Alwani, "The Quranic Model", 33-6.

67. Ibid.

68. Chapter 65 entitled "The Divorce" in Ibn 'Āshūr, Tafsīr; Sayyd Qutb, In the Shade of the Qur'an (Leiceister [UK]: The Islamic Foundation, 2002).

69. Qur'ān 65:8: "How many populations that insolently opposed the command of their Lord and of His messengers did We not then call to severe account? And We imposed on them an exemplary punishment?"

70. Alwani, "The Quranic Model", 44. See also Abd al Ati, The Family Structure in Islam.

71. The long complicated development and changes that were encountered by the Muslims - especially modernisation - had a significant impact on their legal system and social tradition. For an intellectual 
and critical analysis of these developments in the legal, political, and social institution in the Muslim world see the contributions by Ṭāriq al-Bishrī, 'Abd al-Wahhāb al-Mișrī and others in 'Abd al-Wahhāb al-Mișrī (ed.), Doctrine of Bias (Herndon VA: International Institute of Islamic Thought, 1997) (in Arabic). See also Amira Sonbol, "Adults and Minors in Ottoman Shari'a Law and Modern Law", in eadem (ed.), Women, 236-56; Al-Sayyid Marsot, "Women".

72. Amira El Azhary Sonbol, "Law and Gender Violence in Ottoman and Modern Egypt", in eadem (ed.), Women, 277-90.

73. Ibid.

74. Kazimov, "Egypt's Reservations", 36-7. 